\title{
Disease Closure through Opening Novel Chrono-Sciences: Bioprocessing of Intermediary Metabolism
}

\section{Akbar Nikkhah*}

Chief Highly Distinguished Professor, Department of Animal Sciences, University of Zanjan, Iran

While deeply important, timing of nutrient intake and bioprocessing has been mostly overlooked in modern medical and nutritional sciences and public health policies. Glucose by humans is not well tolerated during evening and night times unlike morning and day time. From a chronophysiological standpoint, activity demands glucose and thus day - and not night - is the right time to bioprocess any glucose overflow $[1,2]$. This editorial authorizes a realistic recommendation to minimize evening and nocturnal eating and bioprocessing of especially sugars and starches to promote health through reducing risks from splanchnic and abdominal adiposity, metabolic syndrome, obesity, diabetes, hypertension, and cardiovascular abnormalities. The basis for such an advice includes the most recent discoveries on handling intermediary metabolism in sophisticated animal models.

A more profound understanding of human physiology is enabled by optimal understanding of comparative animal physiology. Ruminants as sophisticated working models for studying human metabolism possess adequately integrative systems ecology, serving postmodern investigations at gene, cell, organ and whole body levels [3-5]. Nocturnal vs. diurnal feed delivery to dairy cows can increase intake rate and postprandial rumen release of metabolites [4-6]. Night feeding, also, improves milk energy production and nutrient utilization efficiency in dairy and beef ruminants [6,7]. These findings underline the biological significance of eating timing in orchestration of nutrient partitioning and metabolic health [8-10].

The early morning glucose upsurge occurs usually in the expectation of the activity period and is called 'dawn-phenomenon'. This glucose peak along with a rise in corticosterone helps to elevate glucose supply and bioprocessing, which in turn raises insulin demands [7]. Reduced glucose tolerance overnight may partially be due to higher melatonin that basically originates from lower glucose bioprocesing capacity and needs of the night. Avoiding large evening and night food meals can allow human endocrinology to better cope with the external circadian environment towards improved nutrient bioprocessing and general health [11-13].

The major philosophy is to help smoothly bioprocess and synchronize the internal rhythms of cell physiology with the shifting environment. Should effectively accomplished, this synchrony could largely ease brain and heart work and successfully reduce risks of metabolic disorders.

In brief, animals of particularly livestock provide appropriate metabolic models for testing innovative hypotheses in human medicine and nutrition [11]. This is increasingly important as the postmodern man is facing complicated issues such as diabetes, various cancer and nervous system related diseases. Farm animals could open novel horizons into closing such rising health hurricanes. This is certainly a practical tool to bioprocess intermediary metabolism to improve health.

\section{Acknowledgments}

The Iran's Ministry of Science Research and Technology, National Elite Foundation, and University of Zanjan are gratefully acknowledged for supporting the author's global programs of optimizing science edification in the new millennium.

\section{References}

1. Nikkhah A (2012) Eating time modulations of physiology and health: life lessons from human and ruminant models. Iran J Basic Med Sci 15: 891-899.

2. Nikkhah A (2011) Ruminant chronophysiological management: an emerging bioscience. Open Access Anim Physiol 3: 9-12.

3. Nikkhah A (2013) Chronophysiology of ruminant feeding behavior and metabolism: an evolutionary review. Biol Rhythm Res 44: 197-218.

4. Nikkhah A (2011) Bioscience of ruminant intake evolution: feeding time models Adv Biosci Biotechnol 2: 271-274.

5. Nikkhah A (2014) Timing of eating a global orchestrator of biological rhythms: dairy cow nitrogen metabolism and milk fatty acids. Biol Rhythms Res 45: 661670 .

6. Nikkhah A, Furedi CJ, Kennedy AD, Crow GH, Plaizier JC (2008) Effects of feed delivery time on feed intake, milk production, and blood metabolites of dairy cows. J Dairy Sci 91: 4249-4260.

7. Nikkhah A (2011) Time of Feeding an Evolutionary Science, Lap Lambert Publishing, GmbH \& Co. KG, Germany.

8. La Fleur SE (2003) Daily rhythms in glucose metabolism: suprachiasmatic nucleus output to peripheral tissue. J Neuroendocrinol 15: 315-322.

9. Nikkhah A (2011) Science of eating time: A novel chronophysiological approach to optimize glucose-insulin dynamics and health. J Diabetes Mellitus 2: 8-11.

10. Nikkhah A (2014) Eating timing and diabetes. Int J Diabetol Vas Dis Res 2: 101

11. Nikkhah A (2014) Ruminants as sophisticated applicable models for human medical research. J Dairy Vet Anim Res 1: 00014.

12. Nikkhah A (2014) Review: Ruminant feed intake regulation evolution: Chronophysiological rhythms perspectives. Biol Rhythm Res 45: 563-577.

13. Nikkhah A (2014) Timing of feeding: a postmodern management strategy to modulate chronophysiological rhythms in rumen fermentation kinetics. Bio Rhythm Res 45: 533-540.

${ }^{*}$ Corresponding author: Akbar Nikkhah, Chief Highly Distinguished Professor Department of Animal Sciences, Faculty of Agricultural Sciences, University of Zanjan, Zanjan, Iran, National Elite Foundation, Tehran, Iran, Tel: +98-24-350328-01; Fax: +98-24-350-332-02; E-mail: nikkhah@znu.ac.ir

Received December 29, 2014; Accepted December 30, 2014; Published January 02,2015

Citation: Nikkhah A (2015) Disease Closure through Opening Novel ChronoSciences: Bioprocessing of Intermediary Metabolism. J Bioprocess Biotech 5 e118 doi:10.4172/2155-9821.1000e118

Copyright: () 2015 Nikkhah A. This is an open-access article distributed unde the terms of the Creative Commons Attribution License, which permits unrestricted use, distribution, and reproduction in any medium, provided the original author and source are credited. 